\title{
Operationalizing the social-ecological system framework to assess residential forest structure: a case study in Bloomington, Indiana
}

\author{
$\underline{\text { Mikaela L. Schmitt-Harsh }}^{1}$ and Sarah K. Mincey ${ }^{2}$
}

\begin{abstract}
Many actors, from the individual to neighborhood to municipal scale, influence the management of trees, grass, and other vegetation on residential properties. Recent work has been directed toward understanding the ecological characteristics of residential landscapes and the human drivers of landscape management; however, much of this work remains disciplinarily focused and at a single scale of analysis. This study employs a mixed-method approach to examine household- and neighborhood-scale drivers of urban residential tree species richness and tree canopy structure. A stratified sampling design was used to capture households in homeowners associations (HOAs) and neighborhood associations (NAs) to better understand the informal and formal institutions having an impact on residential tree management practices. We used the social-ecological system (SES) framework to build a classification system for identifying significant variables that influence residential tree composition and cover. Results of this work demonstrated tree species richness and canopy cover to be positively related to tree abundance and housing age, which is suggestive of the legacy effect. Governance variables were more strongly correlated with tree species richness whereas variables reflecting socioeconomic status and education were more strongly correlated with canopy cover. Rule compliance and fitting in with neighborhood landscaping norms was significantly more important to HOA households than NA households. Conversely, opportunities to work together to solve community problems were viewed more positively by NA households than HOA households. For all parcels together, compliance with city and HOA/NA rules was negatively related to tree species richness and canopy cover, a finding that may implicate the nature of rules that focus on tree removal practices and barriers to plant (what and where). This work is timely given the rapid expansion of neighborhood associations in urban areas, which parallels establishment of rules governing residential yard practices. If current arboriculture and urban forestry standards are considered during rule formation and implementation, such rules have the potential to promote species diversity and the sustained provisioning of ecosystem services.
\end{abstract}

Key Words: institutions; interdisciplinary methods; residential tree diversity; social-ecological system (SES) framework

\section{INTRODUCTION}

Humans at various scales, from households to neighborhoods to governments, are part of urban ecosystems and their collective decisions are integral to sustaining the character and functionality of residential landscapes. Several recent studies have written about the role and impact of these diverse urban actors on residential landscape dynamics (Chowdhury et al. 2011, Cook et al. 2012) with significant attention directed toward the drivers of residential lawn care and herbaceous vegetation (Larsen and Harlan 2006, Yabiku et al. 2008, Larson et al. 2009, Goddard et al. 2013). Such work has demonstrated residential lawns to be locations of high biodiversity and ecosystem services, though considerable heterogeneity exists as a function of socioeconomic and lifestyle factors, built form, and housing age (e.g., Hope et al. 2003, Kinzig et al. 2005, Grove et al. 2006).

A small but growing area of research examines the ecology of residential forests (Schmitt-Harsh et al. 2013) and the care and management of residential trees, including residents' motivations and rationales for planting and removing trees (Shakeel and Conway 2014, Conway 2016). In many urban landscapes, the majority of trees and potential planting sites are located on residential property (Dwyer et al. 2000, Troy et al. 2007), suggesting the need to understand how residential landscapes are being managed and the institutions that foster or constrain sustainable tree-care practices.
As organizing mechanisms for human action, a number of institutions, i.e., rules, norms, and strategies that endure through social organization and interaction (Crawford and Ostrom 1995, McGinnis and Ostrom 2014), have been found to be influential in determining residential yard practices. These include both informal and formal institutions, including community and cultural norms (Nassauer et al. 2009, Blaine et al. 2012); neighborhood covenants, codes, and restrictions (CCRs) that outline what residents can and cannot do to their house and property (Martin et al. 2003, Fraser et al. 2013, Wentz et al. 2016); and municipal regulations, such as ordinances, that may restrict or place controls on lawn maintenance activities, including fertilization and irrigation (e.g., Robbins et al. 2001). Though residential trees are part of, and integral to, the residential landscape, a comprehensive and systematic examination of the institutions shaping residential tree-care practices lags behind those examining lawn maintenance activities (e.g., mowing, fertilizing, landscaping; e.g., Robbins et al. 2001, Cook et al. 2012, Fraser et al. 2013).

Further, although recent studies have directed attention to the ecology and management of residential landscapes, much of the aforementioned research remains disciplinarily focused, despite recognition that residential landscapes are sites of complex socialecological dynamics in which multiple drivers (at the household, neighborhood, and municipal level) influence and interact with biophysical processes at a range of scales (Cook et al. 2012). For

${ }^{1}$ Department of Interdisciplinary Liberal Studies, James Madison University, ${ }^{2} \mathrm{O}$ 'Neill School of Public and Environmental Affairs, Indiana University 
example, household surveys have been frequently employed to understand residents' preferences for certain yard features and their tree management practices (e.g., Larson et al. 2009, Shakeel and Conway 2014, Avolio et al. 2015a, Conway 2016), while the form and function of yards has been studied separately using ecological surveys or canopy analysis (e.g., Smith et al. 2006, Schmitt-Harsh et al. 2012). Rarely have interdisciplinary approaches been utilized that integrate socioeconomic data with parcel data to understand the linkages between drivers and ecological outcomes of tree management decisions (though for exceptions see Martin et al. 2003, Avolio et al. 2015b). Such interdisciplinary approaches are fast becoming common in the study of residential lawn dynamics (e.g., Goddard et al. 2013, Locke et al. 2018, Avolio et al. 2020), though discussion of tree composition and cover is often not a focus.

This study employs a mixed-method approach, including household survey questionnaires, ecological surveys, and tree canopy analysis, to examine household- and neighborhood-scale factors associated with urban residential tree composition and cover. Ecological surveys were completed in the front and back yards of residential properties in Bloomington, Indiana. Specifically, we explored (1) property-level characteristics, household socioeconomic and demographic characteristics, and residents' perceptions of neighborhood institutions, and (2) how such variables relate to and vary between two tree measures, i.e., parcel-scale tree species richness and canopy cover.

To model the interactions between social drivers at multiple scales of analysis and ecological outcomes, we utilized the socialecological systems (SES) framework (Ostrom 2007, 2009, McGinnis and Ostrom 2014). A number of frameworks have emerged to conceptualize and operationalize social-ecological system dynamics (e.g., human-environment system framework, ecosystem services framework, the natural step framework; see Binder et al. 2013 for a review). These frameworks provide different types of diagnostic insights, with the prevalence of institutions and the clarity of defining institutions varying extensively. Those that include institutions frequently embed them as minor exogenous factors, or broadly define them such that institutional dynamics are difficult to operationally incorporate into empirical analysis (Mincey et al. 2013a).

We selected the SES framework because it provides a systematic and comprehensive method for defining social-ecological system attributes and identifies those that may be associated with outcomes of interest. Although the SES framework has been broadly applied to the study of fisheries, community forests, irrigation systems, and more, no such effort has been previously undertaken to operationalize the SES framework to the study of private parcel-scale, urban residential trees.

\section{Using the social-ecological systems (SES) framework to examine residential forest actors and institutions}

One of the most comprehensive frameworks for conceptualizing the relative importance of various institutional mechanisms on equal footing with biophysical and household-scale factors is the SES framework (Ostrom 2009, McGinnis and Ostrom 2014, Partelow 2018; Table 1). The framework links attributes of the physical world (the resource system, RS, and resource units, RU) with those of institutions (governance systems, GS) that define a set of rules for actors (actors, A). All of them influence the resultant interactions $(\mathrm{I})$ and outcomes $(\mathrm{O})$ and create feedbacks. The framework unpacks these first-tier components to reveal second- and third-tier variables at scales relatable to decisionmaking arenas (for example, households to neighborhoods to city government).

Table 1. First- and second-tier social-ecological system (SES) variables from McGinnis and Ostrom (2014) and Basurto et al. (2013), modified from Ostrom $(2007,2009)$. Variables in bold text denote the variables operationalized in this paper.

\begin{tabular}{|c|c|}
\hline \multicolumn{2}{|c|}{$\begin{array}{l}\text { Social, economic, and political settings (S) } \\
\text { S1- Economic development. S2- Demographic trends. S3- Political } \\
\text { stability. } \\
\text { S4- Other governance systems. S5- Markets. S6- Media organizations. S7- } \\
\text { Technology. }\end{array}$} \\
\hline source systems (RS) & ${\text { Governance systems }(\mathrm{GS})^{\dagger}}^{\dagger}$ \\
\hline 1- Sector (e.g., water, forests, & GS1- Policy area \\
\hline isture) & GS2- Geographic range \\
\hline S2- Clarity of system boundaries & GS3- Population \\
\hline S3- Size of resource system & GS4- Regime type \\
\hline S4- Human-constructed facilities & GS5- Rule-making organizations \\
\hline S5- Productivity of system & GS6- Rules-in-use \\
\hline S6- Equilibrium properties & GS7- Norms and strategies \\
\hline S7- Predictability of system & GS8- Network structure \\
\hline namics & GS9- Monitoring \\
\hline \multicolumn{2}{|l|}{ RS9- Location } \\
\hline Resource units (RU) & Actors (A) \\
\hline U1- Resource unit mobility & A1- Number of relevant actors \\
\hline U2- Growth or replacement rate & A2-Socioeconomic attributes \\
\hline U3- Interaction among resource & A3- History or past experiences \\
\hline nits & A4- Location \\
\hline U4- Economic value & A5- Leadership/entrepreneurship \\
\hline $\begin{array}{l}\text { U5- Number of units } \\
\text { U6- Distinctive characteristics }\end{array}$ & $\begin{array}{l}\text { A6- Social capital (trust and } \\
\text { reciprocity) }\end{array}$ \\
\hline $\begin{array}{l}\text { U7- Spatial and temporal } \\
\text { istribution }\end{array}$ & $\begin{array}{l}\text { A7- Knowledge of SES/mental } \\
\text { models }\end{array}$ \\
\hline & $\begin{array}{l}\text { A8- Importance of resource } \\
\text { (dependence) }\end{array}$ \\
\hline & A9- Technologies available \\
\hline \multicolumn{2}{|c|}{ Interactions $(\mathrm{I}) \rightarrow$ outcomes $(\mathrm{O})$} \\
\hline 1- Harvesting & O1-Social performance measures \\
\hline 2- Information sharing & (e.g., efficiency, equity, \\
\hline 3- Deliberation processes & accountability, sustainability) \\
\hline 4- Conflicts & O2- Ecological performance \\
\hline 5- Investment activities & measures \\
\hline 6- Lobbying activities & (e.g., resilience, biodiversity, \\
\hline 7- Self-organizing activities & sustainability) \\
\hline I8- Networking activities & O3- Externalities to other SESs \\
\hline \multicolumn{2}{|c|}{$\begin{array}{l}\text { I9- Monitoring activities } \\
\text { I10- Evaluative activities }\end{array}$} \\
\hline \multicolumn{2}{|c|}{ I10- Evaluative activities } \\
\hline $\begin{array}{r}\text { Related ecos } \\
\text { ECO1- Climate patterns. ECO2- } \mathrm{P} \\
\text { and out o }\end{array}$ & $\begin{array}{l}\text { ystems (ECO) } \\
\text { ollution patterns. ECO3- Flows into } \\
\text { f focal SES. }\end{array}$ \\
\hline
\end{tabular}

Second-tier variables in the GS tier align with revisions proposed by McGinnis and Ostrom (2014) and operationalized by Basurto et al. (2013).

The SES framework, supported by a long history of empirical research on the commons, institutions, and collective action was originally designed as a theoretical framework to advance collective action theory; however, it is now used by many as a tool to diagnose the sustainability of social-ecological systems (Leslie 
et al. 2015, Partelow 2018). To date, the SES framework has been applied to a wide variety of empirical contexts, with a large focus on community-based systems such as irrigation systems (e.g., Cox 2014), small-scale fisheries (e.g., Basurto et al. 2013, Leslie et al. 2015), and forests (e.g., Fleischman et al. 2010). Other scholars have applied the SES framework to general food production systems, aquaculture systems, terrestrial conservation and rangeland management, watershed management, marine conservation and marine ecosystem management, coastal development, energy systems, and pollution management (see Partelow 2018 for a review). Though the SES framework has been widely cited as a tool for advancing empirical SES research and progressing sustainability science, few studies actually operationalize the framework and even fewer do so using an interdisciplinary, mixed-methods approach (see Partelow et al. 2018).

The framework is designed for application to common-pool resource management situations (McGinnis and Ostrom 2014), which by definition preclude trees on private residential property. However, future increases in canopy cover and the ecological services provided by urban trees will depend on the activities of both public and private property owners. Residential parcels may have the largest impact on urban forests because they make up the majority of the urban land base (Dwyer et al. 2000). Although tree planting and maintenance activities associated with a single, small residential parcel may have little impact on the overall urban forest, collectively, homeowners can play a significant role in determining the biodiversity and overall canopy cover of the landscape (Dilley and Wolf 2013). Thus, urban forest managers and neighborhood associations wishing to increase canopy cover or tree species richness would benefit from examining the institutional mechanisms that encourage (or constrain) residents to plant and maintain trees on their properties. Figure 1 provides a conceptual framework for our work, identifying the common actors and types of institutions affecting the management of residential trees. Hereafter, the resource system (RS)is the urban forest, and the resource units (RU) are the residential trees managed by homeowners. The governance system (GS) includes rules-in-use, and norms and strategies that pertain to neighborhood associations. These determine incentives and behavior for actors (A) involved in the care and management of residential trees.

Substantive work has been done to build upon and improve the SES framework from its original proposed state (Ostrom 2007). We incorporate modifications that have been proposed and operationalized by Basurto et al. (2013), McGinnis and Ostrom (2014), and many others after. Of note are revisions to the actors (A) tier and the institutional mechanisms framed in the governance systems (GS) tier. A number of new second-tier variables have been added (see Table 1 and Basurto et al. 2013), and three of the original second-tier variables, including operational rules (now GS6.2), collective-choice rules (GS6.3), and constitutional rules (GS6.4), have been moved to a third tier. All of these are now categorized under "rules-in-use" (GS6). Norms and strategies (GS7) are parsed out from social capital (A6) in the revised framework (Basurto et al. 2013), and here.

\section{METHODS}

\section{Study location}

This research was carried out in the City of Bloomington, Indiana, located in Monroe County approximately 50 miles southwest of the state capital of Indianapolis (Fig. 2). Bloomington's population was most recently recorded (in 2017) as approximately 85,000 individuals with upward of 33,200 housing units (U.S. Census Bureau 2010). The city is situated in the Norman Upland Plateau physiographic region of Indiana, with variable topography typical of the unglaciated portion of the state (Hill 2011).

Fig. 1. Conceptual framework of the common actors and types of institutions affecting the management of residential forests. Solid lines represent formal institutions or rules and dashed lines represent informal institutions or norms/strategies. Arrows indicate the primary direction of institutional influence. Modified from Mincey et al. (2013a).

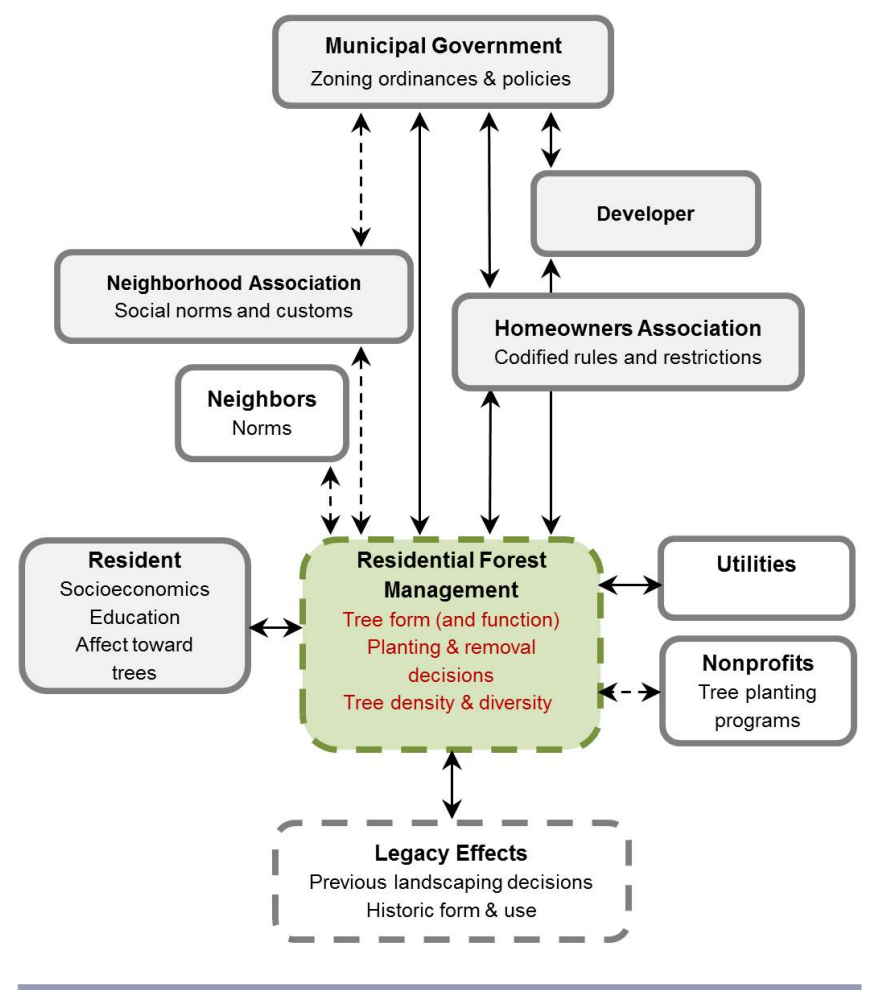

The City of Bloomington has long-standing, well-documented policies focused on the care and management of urban trees. The city was recognized by the National Arbor Day Foundation in 1984 as Indiana's first Tree City USA. Since that time, Bloomington has successfully met all criteria needed to keep its Tree City USA designation, including a tree board or commission, a tree care ordinance, a community forestry program with an annual budget of at least US\$2 per capita, and an Arbor Day observance and proclamation. 
Fig. 2. Map of the 14 study neighborhoods in the City of Bloomington, Indiana. Note: HOA = homeowner association; NA $=$ neighborhood association.

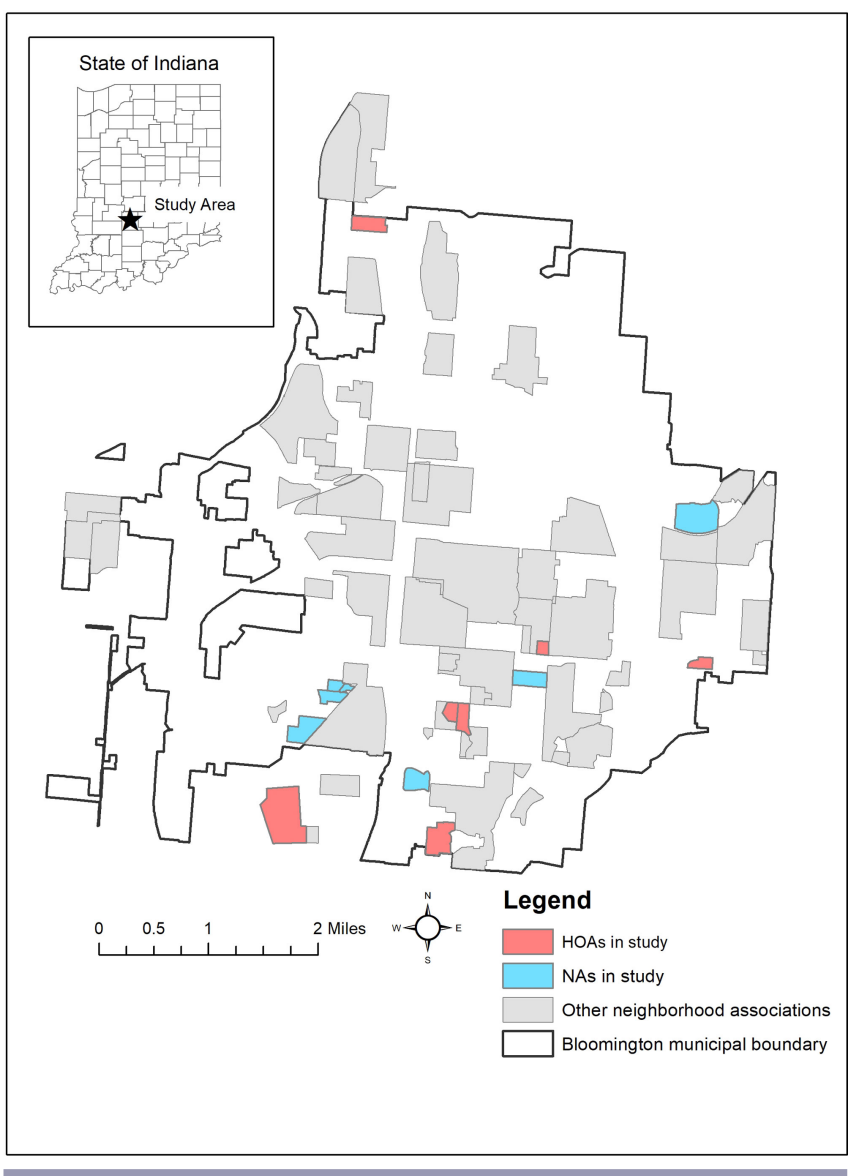

Bloomington's Unified Development Ordinance (UDO; McBride, Dale, Clarion 2019) and the Bloomington Tree Ordinance determine city-level policies regarding urban tree management and influence all parcels within the city. The UDO, adopted in 2007 and amended in 2018, stipulates that a specific percentage of tree canopy cover must be retained during land development depending on the baseline canopy of a site (McBride, Dale, Clarion 2019; 20.05.044). For example, any property with a baseline canopy cover of $50 \%$ is required to retain $70 \%$ of that canopy during development. In practice, this would mean that a 1 -acre property with $50 \%$ canopy cover (i.e., 0.5 acres) would be required to maintain at least 0.35 acres $(0.5$ acres $x 70 \%)$ during development. This environmental standard applies to nearly every zoning district in the city, including single-family residential zones. The UDO also includes a number of additional tree planting and canopy cover provisions, including (1) preferencing native trees, undisturbed or virgin woodlands, and older forest growth over younger stands of trees (Environmental Standards; Tree and Forest Preservation; 20.05.044), (2) provisions for the number, type, and location of trees planted along streets (Landscaping Standards; 20.05.052) and in parking lots (Landscaping Standards; Parking; 20.05.053), and (3) a list of permitted plant species based on characteristics and location (20.05.058).
In addition to the tree canopy cover provisions in the UDO, Bloomington's Tree Ordinance (Bloomington Municipal Code 12.24, Trees and Flora https://library.municode.com/in/ bloomington/codes/code_of_ordinances?nodeId=TIT12STSISTSE) requires that abutting property owners manage street trees in the public right of way (PROW) and private boundary trees (those that influence public space). Owners are required to remove all dead, diseased, or dangerous trees; prune the branches of such trees to avoid obstructing traffic signs, street intersections, or street lamps; and provide clearance of tree branches above streets and sidewalks. The ordinance further requires that homeowners obtain a permit to plant, remove, or prune branches greater than three inches in diameter within the public right of way. The permit process is not arduous nor intended to discourage homeowners from planting trees. Any violations to the provisions of the Tree Ordinance result in a written notice of violation, followed by a penalty where warranted. The ordinance has been in effect since 1992 and is included in the Bloomington Tree Care Manual (see https://issuu.com/bloomingtonparks/docs/tree care manual 4th_edition_0117). The Manual, now in its fourth edition, serves as an arboricultural specification manual for homeowners and tree stewards.

\section{Sample design}

Our study area includes 14 residential neighborhoods within Bloomington (Fig. 2). Three factors were used to select the neighborhoods: housing structure type, average date of house construction, and size of neighborhood. Studies have shown these variables to be influential to residential tree-cover patterns (Landry and Chakraborty 2009, Shakeel and Conway 2014), and selections based on these factors enabled us to place temporal (age of housing) and ownership (structure type) controls on our samples.

First, neighborhoods in which owner-occupied, single-family housing units dominated the neighborhood were selected. This ensured most households had access and ownership to a yard. We utilized county tax assessor shapefiles and city zoning boundaries to identify neighborhoods with this criterion. In generating this sample, we avoided the core of the city (defined by a radius of approximately two kilometers from the city center) in which residential lands tend toward high density.

Second, the 14 neighborhoods were chosen to represent a specific combination of 2 control variables: age and neighborhood size (the number of parcels with the neighborhood). At the time of data collection, Bloomington had 49 neighborhood associations (NAs) and approximately 65 homeowners associations (HOAs). Some of these neighborhoods were established prior to the $1950 \mathrm{~s}$ whereas others were established within the decade. Similarly, some had over 400 parcels within the neighborhood whereas others had fewer than 50 parcels. We aimed to capture the heterogeneity of neighborhoods and their associated rules and norms associated with tree management. Online GIS data provided by the county were utilized to compute neighborhood age and size. Given the number of parcels within the 100+ neighborhoods, we randomly selected $10 \%$ of parcels for each neighborhood to extract information pertaining to age of construction. The age of the neighborhood was then computed as an average of all parcels selected. The size of neighborhoods was determined by a direct count of the number of parcels within each neighborhood using the county GIS data. 
We selected older communities $(\leq 1985)$, newer communities ( $>$ 1986), small communities ( $\leq 85$ parcels), and large communities ( $>86$ parcels). These thresholds were set by examining the distribution and variance of community age and size across the whole city. In addition, the breakpoint of 1985 was chosen because neighborhoods built before approximately 1985 hold the potential to have mature canopy, whereas newer neighborhoods' canopy extent is likely not fully mature. We recognize these thresholds may not be applicable to other municipalities but they enabled us to identify neighborhoods more selectively and without bias. Our stratification resulted in 14 neighborhoods, 7 of which maintain HOAs, the remaining 7 maintain NAs. For all homeowners associations, covenants, codes, and restrictions (CCRs) were obtained and analyzed for any content related to tree-care provisions.

\section{Household survey}

To obtain individual household data from residents in our study area, a mail-based survey was sent to all owner-occupied parcels within the 14 neighborhoods ( 1100 households). These were later followed by reminder postcards and a replacement survey per the Dillman Method (Dillman 2007). Households were contacted up to four times. A unique code on each survey was used to track responses and match completed surveys with other property-level data.

The survey asked property owners basic questions about their demographic and property characteristics, the planting and removal of trees, and purported benefits and costs associated with trees on their property. A set of closed-and open-ended questions asked respondents about rules and strategies related to tree planting and removal, including city-level rules and NA or HOA rules. Approximately half of the 37-question survey was formatted in a simple multiple-choice format in which respondents identified, for example, their familiarity with neighborhood programs and their participation in neighborhood tree planting or planning programs. The remaining half asked respondents to indicate their level of agreement to questions about their neighborhood including the importance of fitting in and the effectiveness of the HOA (or NA) to monitor and enforce maintenance of yard and tree-care practices. Such questions were used, for example, to ascertain respondents' perceptions about rules and rule compliance as they relate to tree care. The survey questions analyzed can be found in the supplementary materials (Appendix 1). Returned surveys were input into Microsoft Excel, screened for errors and omissions, and exported to SPSS Statistics 26 for analysis.

A total of 420 surveys were returned (38\% response rate) from which 230 respondents cited their willingness to have their parcel inventoried. From this set of 230, we randomly selected 100 parcels to be inventoried in the summer, ensuring at least $10 \%$ of all communities' owner-occupied parcels were represented. One exception was a very large neighborhood ( $>400$ parcels) in which we sampled $\sim 3 \%$ of parcels because of time/budget constraints. All results reported here are based on the 100 parcels for which we have both household survey data and field data.

\section{Tree canopy and field inventory}

A census of all trees was conducted at each of the 100 parcels. All trees with diameter at breast height $(\mathrm{DBH}) \geq 2.5 \mathrm{~cm}$ were identified to species level, geo-located using a Trimble GeoExplorer 2008
GeoXH GPS unit, and measured for their DBH (at $1.37 \mathrm{~m}$ above surface) and height (via a Nikon Forestry 550 laser rangefinder/ hypsometer). Trees inventoried included front and backyard trees, and trees in the public-right-of-way (PROW) adjacent to the sample parcel. As a separate component of the project, soil samples were collected and analyzed at each parcel to determine parcel-scale bulk density, organic carbon, and nitrogen. For more on this work, see Schmitt-Harsh et al. (2013).

Parcel-level tree species richness was determined by direct observation during tree identification. To calculate percent canopy cover, National Agricultural Imagery Program (NAIP) imagery at $1-\mathrm{m}$ spatial resolution was used. Images were mosaicked without enhancements then clipped to a modified and buffered Bloomington city boundary. A decision-tree classification procedure that used manual selection of spectral thresholds for specified land-cover classes was used, followed by a maximum likelihood supervised classification to separate forest and nonforest classes (for more on this classification, see Mincey et al. 2013b). The classification was completed for the whole city, with resulting classes including trees and shrubs (existing canopy cover), grasses/turf (potential canopy cover), and other (e.g., impervious surface, soil, water). The classification accuracy, based on 283 points manually selected using the NAIP imagery, equaled $93.3 \%$, with classification errors predominantly stemming from confusion of grasses/turf with the other land class.

Percent canopy cover per parcel was calculated using a GIS property boundary layer that was provided by the City of Bloomington Information and Technology Services Department. All canopy over a given parcel was included in the calculation regardless of stem location. In the study area, property boundaries included the street and city-owned boulevard (grass strip and/or sidewalk) in front of houses because Bloomington's Tree Ordinance requires property owners to manage street trees in the PROW.

Operationalizing the social-ecological system (SES) framework We combined data collected from the parcel inventory and household survey to operationalize the SES framework to two outcomes of interest, tree species richness and canopy cover, at the residential parcel scale. These measures were selected given widespread and persistent management efforts focused on the diversification of species on private parcels and in public spaces. Maintaining high tree-species richness has been associated with promotion of a robust and resilient urban forest, and sustained provisioning of ecosystem services (Clark et al. 1997, Alvey 2006, Kenney et al. 2011, Hale et al. 2015, Conway et al. 2019). Further, many municipalities have (or are developing) tree-canopy goals, and the management and reestablishment of trees on private residential lands is a critical component to achieving such goals. Using two outcomes associated with sustainable urban forests allowed us to assess and compare potential variation in their drivers.

Table 2 displays the variables selected to operationalize the SES framework to urban residential properties. First-tier variables represented include the resource system (RS), resource units (RU), the governance system (GS), the actors (A), and outcomes (O). Within the first-tier variable, RS, two second-tier variables (resource size, RS3, and human constructed facility, RS4) were 
Table 2. The social-ecological system (SES) variables operationalized in the analysis of residential forest structure. Note: HOA = homeowners association; $\mathrm{CCR}=$ covenants, codes, and restrictions; NA = neighborhood association; NAIP = National Agricultural Imagery Program.

\begin{tabular}{llll}
\hline \hline \multicolumn{2}{l}{ SES Framework } & Variables Operationalized & \\
\hline $\begin{array}{l}\text { First-Tier } \\
\text { Variables }\end{array}$ & Second-Tier Variables & Name & Description \\
$\begin{array}{l}\text { Resource } \\
\text { System (RS) }\end{array}$ & RS3- Resource size & Available planting space & $\begin{array}{l}\text { Calculated from city shapefiles as the total lot size (RS3) less any area } \\
\text { occupied by buildings and impermeable surfaces such as driveway (RS4). }\end{array}$
\end{tabular}

facility

Ecosystem history ${ }^{\dagger} \quad$ Home age (years)

Resource

Unit (RU)

Actors (A)

RU5- Number of units
A1- Number of relevant actors

A2- Socioeconomic attributes

A2- Socioeconomic attributes household
Education

A2- Socioeconomic attributes

Income

A6- Social capital

Resident age

Neighborhood cohesion

A7- Knowledge of SES

Resident time at parcel (years)

Governance GS6- Rules-in-use (Operational, Rule compliance System (GS) GS6.2)

GS6- Rules-in-use (Collective choice, GS6.3)

Collective problem solving

GS6- Rules-in-use (Constitutional, GS6.4) GS7- Norms and strategies

Constitutional

Norms

Outcomes O2- Ecological performance

(O)

O2- Ecological performance
Tree species richness

Parcel-level canopy cover (\%)
The age of the home (calculated as the survey year less the year in which the respondent' home was built). Data obtained from the Monroe County tax assessor database.

The number of trees on the parcel, including in the front yard, back yard, and public right-of-way.

Household's response to a question about the number of people residing in the household less any individuals younger than 18 years of age.

Coding of the respondent's education level into three categories (high school or equivalent, 1; some college technical, 2; college grad or higher, 3 )

Coding of the household's income into four categories ( $<$ US $\$ 25,000,1$; US\$25,001-50,000, 2; US\$50,001-75,000, 3; > US\$75,000, 4)

Coding of the resident's age into 5 categories ( $<35$ years, 1 ; $35-44$ years, 2 ; $45-54$ years, $3 ; 55-64$ years, 4 ; > 65 years, 5 )

A scale based on three survey questions asking respondents to rate their level of agreement to statements about neighborhood trust, reciprocity, and cohesion. Scale represents the average of three responses, each with the code: disagree, 1 ; neutral, 2 ; agree, 3 .

The length of time the respondent has resided on the property.

Coding of the household's response to a question about the importance of compliance with city and community rules regarding landscape management (not important, 1; somewhat important, 2; very important, 3)

A single item on the survey, asking respondents how strongly they agreed to a statement about their neighborhood's ability to work together to solve community problems (disagree, 1 ; neutral, 2; agree, 3 ).

Residential properties in HOAs (CCRs present) coded as 1; residential properties in NAs coded as 0 .

A single item on the survey, asking respondents to rate the importance of fitting in with the neighborhood in determining tree and yard maintenance activities (not important, 1; somewhat important, 2; very important, 3) The number of different tree species on the parcel. Data obtained from ecological surveys of front and back yards.

Existing canopy cover per parcel at the time of sampling. Spatial resolution of NAIP imagery is $0.5 \mathrm{~m} \mathrm{x} 0.5 \mathrm{~m}$.

$\mp$ "Ecosystem history" is not formalized in the SES framework (Ostrom 2009) but its inclusion has been suggested by Vogt et al. (2015a).

operationalized to compute available planting space. We included another second-tier variable, history of system, to explain the RS, which was operationalized as the age of the home (calculated as the survey year less the year in which the respondent's home was built). This variable is not formalized in the original SES framework but its inclusion has been suggested by Vogt et al. (2015a). Given strong relationships between construction age and residential forest patterns found in other studies (Grove et al. 2006, Luck et al. 2009, Boone et al. 2010), we feel it is an appropriate addition to our modeling efforts. The number of units (RU5), a variable included under the resource-unit (RU) tier, was operationalized as the number of trees located in the front yard, back yard, and PROW of each parcel.

Six second-tier actor variables were examined including the number of relevant actors (A1), operationalized as the number of adults (individuals 18 years or older) residing in the household who may play a role in decision making; several socio-economic (A2) variables including residents' education, income, and age; and residents' knowledge of the SES (A7), interpreted as the length of time the respondent has resided at the property. The three socioeconomic variables were coded categorically (see Table 2 ) in alignment with the survey instrument. Finally, a measure of social capital (A6) was approximated from three survey questions asking respondents how strongly they agreed (scaled to a threepoint scale) that "people in this neighborhood can be trusted," "people in the neighborhood are willing to help one another," and "the neighborhood is close-knit." The scale represents the average of the three responses and is modeled after a previously published social cohesion scale (Sampson et al. 1997, Fraser et al. 2013).

Four second-tier governance systems variables were examined, typologized according to suggestions in McGinnis and Ostrom (2014) and Basurto et al. (2013). Three of these variables fall under 
rules-in-use (GS6), which are defined as formal and informal rules in practice that shape human behavior and govern social interactions. Such rules include operational, collective-choice, and constitutional rules, each of which have varied and sometimes overlapping definitions in the SES literature. For our purposes, rules that provide a regulatory framework outlining permissible (or restricted) landscaping activities, including permissible forms of punishment, are demarcated at the constitutional level (GS6.4). We use this to mean the presence (or absence) of covenants, codes, and restrictions (CCRs) established by associations. Properties in NAs were assigned a value of 0 while properties in HOAs were assigned a value of 1 (regardless of the amount or specificity of rules that are related to tree care; Table 2).

The processes through which institutions are constructed and policy decisions made by actors authorized (or allowed) to do so are defined at the collective-choice level (Basurto et al. 2013). These may include establishment of regular board meetings in which rules about monitoring responsibilities and sanctioning are established. It may also more broadly encompass opportunities that are available to construct rules and/or solve community problems. For our purposes, a measure of collective-choice rules (GS6.3) was approximated from a single survey question that asked respondents their level of agreement to a statement about having viable opportunities to work with their neighbors to solve community problems (Table 2).

Rules governing the implementation of practical decisions by individuals who are authorized (or allowed) are realized at the operational-choice level (Basurto et al. 2013). A measure of operational rules (GS6.2) was approximated from a single survey item that asked respondents to rate the importance of complying with city or NA/HOA rules as they relate to maintaining the property's natural landscape. Finally, we included an assessment of norms and strategies (GS7) given prior work demonstrating the importance of community and cultural norms on residential property decision making (e.g., Nassauer et al. 2009). In contrast to rules-in-use, there is no formal sanctioning in place in association with norms. A measure of norms (GS7) was ascertained from a single survey item that asked respondents the importance of fitting in with the neighborhood in determining their tree and yard maintenance activities.

In total, we assessed the explanatory power of 13 variables on 2 outcomes of interest $(\mathrm{O})$, parcel-scale tree species richness and parcel-scale canopy cover. These explanatory variables have been identified by scholars as being important determinants of urban forest composition and cover at various scales of analysis. For example, within different cities, studies have demonstrated a positive relationship between tree-canopy cover and income (Iverson and Cook 2000, Greene et al. 2018, Nesbitt et al. 2019), tree cover and education (Luck et al. 2009, Nesbitt et al. 2019), and tree cover and home or neighborhood age (Grove et al. 2006, Luck et al. 2009, Boone et al. 2010, Lowry et al. 2012). The former relationships feed into a proposed luxury effect and the latter relationships help support the legacy effect, with older neighborhoods tending to have larger trees and greater tree canopies. In a number of cities, tree-species richness has also been shown to increase with home or neighborhood age (Martin et al. 2004, Clarke et al. 2013) and with household income (Martin et al. 2004, Avolio et al. 2015b).
To our knowledge, few studies have examined relationships between residential parcel area and tree-species richness, or relationships between number of residential trees (abundance) and canopy cover. In natural systems, area is a key determinant of diversity, so we hypothesized that larger parcels will support more species and more canopy. We also hypothesized a positive abundance-canopy relationship (more trees $\rightarrow$ more canopy); however, this relationship may be impacted by the age and maturity of the tree(s), i.e., younger trees have sparser canopy, and tree type (canopy differs between evergreens and broad deciduous). Thus, the relationship may exhibit stronger (or different) signals in urban landscapes that are more homogeneous in housing age and species composition.

\section{Data analysis}

Basic summaries of relevant survey questions were calculated to understand household and property characteristics, and the norms and rules-in-use that have an impact on tree management practices. Using IBM SPSS Statistics 26 software, chi-square tests of independence and Welch one-way ANOVAs (robust to unequal variances) were used to understand variations in SES factors by parcels in HOA and NA neighborhoods (see Table 3). For all tests, results were considered significant at $\mathrm{a} \leq 0.05$ and marginal when $0.05<\mathrm{a} \leq 0.10$.

Ordinary least squares (OLS) linear regressions were used to explore the relationships between tree structure measures (tree richness, canopy cover) and property, household, and institutional variables. Given the high number of independent variables relative to observations, we used backward stepwise OLS regressions to eliminate variables of least importance in predicting parcel-scale tree structure. Variables were removed based on the $F$-test, with the cut-off value set at a $p$-value of 0.10 . The remaining explanatory variables were then input into forward entry OLS linear regression models. Standard test diagnostics were performed to ensure the viability of regression results. Correlations among the explanatory variables were weak, tolerance values (calculated for each regression model) indicated no multicollinearity (variance inflation factors for all variables were less than 2), and the dependent variable residuals followed close-to-normal distributions. The tree-richness variable was transformed to the natural logarithmic form to meet the assumption of normality. The canopy-cover variable was log transformed and subsequently square root transformed, but neither improved model results so we retained the untransformed data in regression analyses.

\section{RESULTS}

Assessment of covenants, codes, and restrictions (CCRs)

Among the 100 parcels surveyed and inventoried, households were split between NAs $(n=48)$ and HOAs $(n=52)$, which subjected them to different institutional arrangements. As expected, HOAs were more institutionally formalized than NAs in our sample, all having a formal governing board with rulemaking and sanctioning power over private parcels. Covenants, codes, and restrictions existed for all HOAs in the sample and were used as community bylaws, which addressed both collectivechoice and operational rules of the communities. Common operational rules were related to maintaining a particular community aesthetic; most required approval of parcel-scale 
changes or additions to built structures, and many simply restricted potential visual negatives, including open garage doors or outdoor laundry lines. The extent to which these bylaws governed tree management was minimal in our sample. The HOA rules generally required parcel-scale removal of dead or dying trees, avoidance of planting within infrastructure easements, and pruning trees to avoid obstructing sight-lines at intersections of roads. In many ways, these rules were the same or extensions of the Bloomington Tree Ordinance.

Table 3. Summary of social-ecological system (SES) data by average parcel overall and average parcel by neighborhood type: homeowner association vs. neighborhood association (HOA vs. NA). Continuous data shown are means and in parentheses, standard deviation. For ordinal data (indicated in bold), data shown are mode and in parentheses, proportion at mode.

\begin{tabular}{|c|c|c|c|c|}
\hline \multirow{2}{*}{$\begin{array}{l}\text { Explanatory } \\
\text { Variables }\end{array}$} & \multirow{2}{*}{$\begin{array}{c}\text { All } \\
\text { Parcels }\end{array}$} & \multicolumn{3}{|c|}{ Comparisons by Association Types } \\
\hline & & $\begin{array}{l}\mathrm{HOA}(\mathrm{n}= \\
52)\end{array}$ & $\begin{array}{l}\mathrm{NA}(\mathrm{n}= \\
48)\end{array}$ & p-value \\
\hline Planting space $\left(\mathrm{m}^{2}\right)$ & $\begin{array}{c}990.77 \\
(562.11)\end{array}$ & $\begin{array}{c}795.85 \\
(562.19)\end{array}$ & $\begin{array}{l}1201.93 \\
(484.79)\end{array}$ & 0.000 \\
\hline Home age (yrs) & $\begin{array}{l}24.40 \\
(16.31)\end{array}$ & $\begin{array}{l}17.79 \\
(9.19)\end{array}$ & $\begin{array}{c}31.56 \\
(19.18)\end{array}$ & 0.005 \\
\hline Tree count & $\begin{array}{c}18.74 \\
(21.10)\end{array}$ & $\begin{array}{l}18.92 \\
(21.86)\end{array}$ & $\begin{array}{l}18.54 \\
(20.48)\end{array}$ & 0.929 \\
\hline $\begin{array}{l}\text { No. adults in the } \\
\text { household }\end{array}$ & $\begin{array}{l}1.81 \\
(0.573)\end{array}$ & $\begin{array}{l}1.83 \\
(0.559)\end{array}$ & $\begin{array}{l}1.78 \\
(0.593)\end{array}$ & 0.643 \\
\hline Education category & $\begin{array}{c}\text { College } \\
\text { grad or + } \\
(78.4 \%)\end{array}$ & $\begin{array}{l}\text { College } \\
\text { grad or }+ \\
(80 \%)\end{array}$ & $\begin{array}{c}\text { College } \\
\text { grad or }+ \\
(76.6 \%)\end{array}$ & 0.555 \\
\hline $\begin{array}{l}\text { Income category } \\
\text { (US\$) }\end{array}$ & $\begin{array}{c}25-50,000 \\
(31 \%)\end{array}$ & $\begin{array}{c}25-50,000 \\
(33.3 \%)\end{array}$ & $\begin{array}{c}25-50,000 \\
(28.6 \%)\end{array}$ & 0.049 \\
\hline $\begin{array}{l}\text { Age category } \\
\text { (years) }\end{array}$ & $\begin{array}{c}55-64 \\
(25.8 \%)\end{array}$ & $\begin{array}{l}>65 \\
(32 \%)\end{array}$ & $\begin{array}{c}55-64 \\
(27.7 \%)\end{array}$ & 0.232 \\
\hline $\begin{array}{l}\text { Neighborhood } \\
\text { cohesion and social } \\
\text { capital }\end{array}$ & $\begin{array}{l}\text { Agree } \\
(54.1 \%)\end{array}$ & $\begin{array}{l}\text { Agree } \\
(50 \%)\end{array}$ & $\begin{array}{l}\text { Agree } \\
(58.3 \%)\end{array}$ & 0.657 \\
\hline $\begin{array}{l}\text { Resident time at } \\
\text { parcel (yrs) }\end{array}$ & $\begin{array}{c}9.54 \\
(9.12)\end{array}$ & $\begin{array}{c}8.83 \\
(8.04)\end{array}$ & $\begin{array}{c}10.59 \\
(10.29)\end{array}$ & 0.623 \\
\hline $\begin{array}{l}\text { Importance of rule } \\
\text { compliance }\end{array}$ & $\begin{array}{c}\text { Somewhat } \\
(38.4 \%)\end{array}$ & $\begin{array}{l}\text { Very } \\
(52.9 \%)\end{array}$ & $\begin{array}{c}\text { Not \& } \\
\text { Somewhat } \\
\text { (both } \\
39.6 \% \text { ) }\end{array}$ & 0.000 \\
\hline $\begin{array}{l}\text { Collective problem- } \\
\text { solving opportunities }\end{array}$ & $\begin{array}{l}\text { Agree } \\
(36.7 \%)\end{array}$ & $\begin{array}{c}\text { Neutral } \\
(38 \%)\end{array}$ & $\begin{array}{c}\text { Agree } \\
(43.8 \%)\end{array}$ & 0.039 \\
\hline $\begin{array}{l}\text { Importance of } \\
\text { norms }\end{array}$ & $\begin{array}{c}\text { Somewhat } \\
(49.5 \%)\end{array}$ & $\begin{array}{l}\text { Very } \\
(49 \%)\end{array}$ & $\begin{array}{c}\text { Somewhat } \\
(56.3 \%)\end{array}$ & 0.003 \\
\hline \multicolumn{5}{|l|}{ Outcomes } \\
\hline $\begin{array}{l}\text { Tree species } \\
\text { richness }\end{array}$ & $\begin{array}{c}7.45 \\
(5.08)\end{array}$ & $\begin{array}{c}7.31 \\
(4.76)\end{array}$ & $\begin{array}{c}7.60 \\
(5.45)\end{array}$ & 0.923 \\
\hline $\begin{array}{l}\text { Existing canopy } \\
\text { cover }(\%)\end{array}$ & $\begin{array}{l}43.37 \\
(20.20)\end{array}$ & $\begin{array}{c}37.64 \\
(21.68)\end{array}$ & $\begin{array}{c}48.26 \\
(17.63)\end{array}$ & 0.024 \\
\hline
\end{tabular}

Compared to HOAs, NAs sampled were institutionally informal. Only one NA within our sample was determined to have CCRs and the only tree management-related rule within those requirements stated that no tree was to be planted in the PROW of the community. Given that this NA had no governing board with formal sanctioning power and had numerous trees in the PROW, its CCRs were considered largely unenforced and were therefore categorized in the model as being absent.

\section{Respondent and parcel characteristics}

In our sample, the physical form of residential parcels varied greatly by association type, with HOA parcels being significantly younger, on average, and smaller in terms of parcel size and plantable area (RS3/RS4; Table 3). For example, the average home age and plantable space of HOA parcels was 18 years and $796 \mathrm{~m}^{2}$, respectively, while the same metrics for NA parcels equaled 32 years and $1202 \mathrm{~m}^{2}$ (Table 3 ). These results were not unexpected given recent trends that signal residential lot-size reductions for newer developments (Larsen and Hall 2008) and rapid expansion of neighborhood associations in recent years, in particular, HOAs (Community Associations Institute 2016). Shrinking lot sizes and front-yard spaces has shifted some focus away from private yard landscaping toward expansion of collective spaces in the neighborhood (Larsen and Hall 2008). In our sample, a review of the CCRs suggests that most HOAs contained common land, owned and managed by the HOA.

Following indications that HOA households were younger than NA households, on average, the residence time for respondents (A7) was lower for HOA parcels $(x=8.8$ years) than NA parcels ( $x=10.6$ years), though the difference was insignificant at the 0.05 level (Table 3 ). Across all parcels, length of residence at the property ranged from 6 months to 41 years. Our sample population was relatively homogeneous in terms of race and education, with the vast majority of respondents identifying themselves as white $(97 \%)$ and a college graduate or higher $(78 \%)$, the latter likely linked to the presence of a large university within the city. Among household characteristics, reported income showed the greatest variability, with $18 \%$ of all respondents reportedly making US\$100,000 or greater, 14\% making between US $\$ 75,000$ and US $\$ 100,000,24 \%$ making between US $\$ 50,000$ and US\$75,000, 31\% making between US\$25,000 and US\$50,000, and 13\% making below US\$25,000. Differences in income between HOA and NA parcels were marginally significant (Table 3), with a larger proportion of households in HOAs falling in the highest income bracket. This may be associated with the fact that HOA households are required to pay association fees for maintenance of common property, a likely financial barrier to residents with lower incomes.

Full parcel ecological surveys demonstrated wide variability in tree-structure characteristics for parcels in both HOAs and NAs (see Schmitt-Harsh et al. 2013 for a detailed discussion of tree and soil characteristics for all inventoried parcels). On average, parcels contained 18.7 individual trees, though some parcels had a single tree on the property whereas others had over 100 trees. Parcel-scale tree density (data not shown in Table 3) also ranged widely from 0.8 to 60 trees per $1000 \mathrm{~m}^{2}$, with an average of 14.7 trees per $1000 \mathrm{~m}^{2}$. Some parcels were characterized by few trees, but maximum tree species richness. For example, a number of parcels with three to five trees had an equivalent number of different species. Parcels with a large number of trees ( $>40$ trees) were characterized by richness values that ranged from 9 to 20 tree species. Collectively, the number of different species found on properties varied from 1 species to 22 species, with an average of 7 different tree species (Table 3). A significant and positive relationship was found between tree abundance and tree richness per parcel (Spearman's $\rho=0.908)$, and between tree abundance and canopy cover per parcel $(\rho=0.623)$. 
Fig. 3. Frequency of responses (in \%) to questions about rule compliance, norms, neighborhood problem solving, and neighborhood cohesion by association type. Note: HOA = home owner association; $\mathrm{NA}=$ neighborhood association.

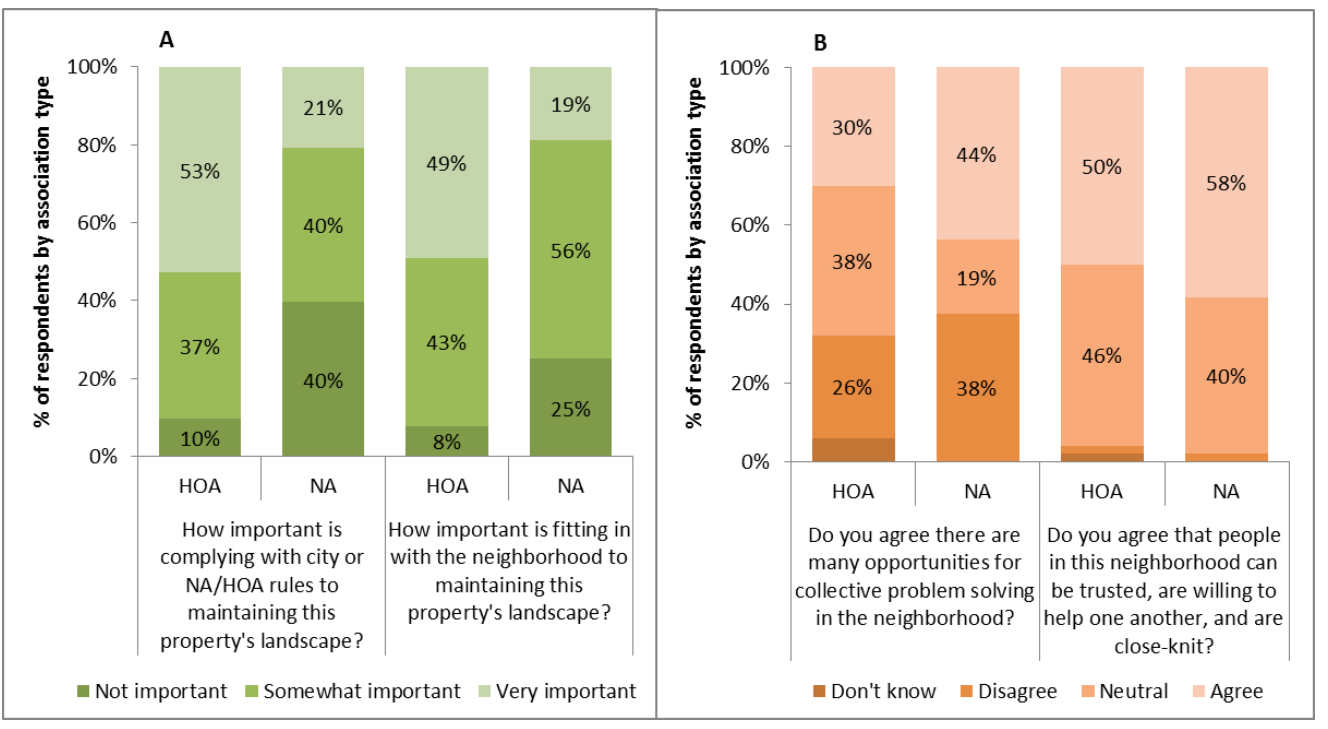

There was no significant difference between the two association types in terms of parcel-scale tree abundance or species richness; however, HOA parcels were characterized by lower canopy cover $(37.6 \%)$ than evidenced in NA parcels (48.3\%; Table 3$)$ and higher tree density $\left(\sim 17\right.$ trees per $\left.1000 \mathrm{~m}^{2}\right)$ than NA parcels $(\sim 12$ trees per $1000 \mathrm{~m}^{2}$; data not shown). These differences are likely explained by the smaller parcel size and plantable space in HOAs, and the younger age of HOA parcels (with resultant impacts on canopy extent).

\section{Rule compliance and neighborhood norms}

Suggestive of the institutional differences described above by association type, HOA households were significantly more influenced by operational rule compliance and community norms in terms of their landscaping choices (Table 3). Across all respondents, households reported that compliance to city and community rules was very important $(37 \%)$ or somewhat important $(38 \%)$ in maintaining their landscaping, with $24 \%$ indicating such rules were not important. Differences were notable when parsing out rule compliance by association type, as $53 \%$ of households in HOAs reported compliance to be very important, in contrast to $21 \%$ of households in NAs (Fig. 3A). Further, $40 \%$ of NA households indicated rule compliance was not important (Fig. 3A).

Fitting in with the neighborhood was deemed very important $(34 \%)$ or somewhat important $(50 \%)$ in maintaining property landscape characteristics across all respondents. Specific to HOA parcels, a larger percentage of respondents indicated the importance of norms, i.e., $49 \%$ cited norms as being very important and another $43 \%$ as somewhat important (Fig. 3A). Norms were also recognized as being important in NAs, though $25 \%$ described them as being not important.

Opportunities to work together to solve community problems was deemed more positively by NA households than HOA households. For example, $44 \%$ of NA households agreed that there are many opportunities to work with their neighbors to solve community problems; this contrasts with the $30 \%$ of HOA households who agreed (Fig. 3B). Finally, although not a governance system as described in the SES framework, we've included the social capital index in Figure 3B. This index provides a measure of social cohesion and reciprocity, which can invariably have an impact on community norms and strategies. For both HOA and NA households, just over $50 \%$ of respondents described their neighbors as being trustworthy and helpful, and their neighborhood as being close-knit. A slightly higher percentage of NA households agreed than HOA households, and although very few disagreed with such assertions, a large percentage remained neutral on the subject (Fig. 3B).

\section{Determinants of parcel-level tree species richness and canopy cover}

When all properties were included, the OLS regression analysis for tree species richness retained seven explanatory variables, with a resulting $\mathrm{R}^{2}$ value of 0.582 (Table 4 ). The number of trees on the property (RU5) was a significant and positive predictor of tree species richness at the 0.01 level. Other significant variables included the homeowner's age (A2), the age of the home (RS), and all three measures of institutional governance, including rule compliance (GS6.2), collective problem solving (GS6.3), and constitutional rules (GS6.4; Table 4). Each of the retained explanatory variables exhibited a positive relationship with tree species richness, with the exception of rule compliance (Table 4).

The OLS regression analyses for percent canopy cover also retained seven explanatory variables, with a resulting $\mathrm{R}^{2}$ value of 0.535 (Table 4). As with the tree species richness model, the number of trees on the property and the age of the home were positively related to property-level canopy cover (Table 4). Other significant variables included the available planting space (RS3/4), respondents' education level (A2), and household income (A2). 
The variable measuring community norms (GS7) was retained in the model but not identified as a significant variable at the 0.10 level. Two variables were negatively related to canopy cover, household income and rule compliance, the latter relationship being common to both OLS models (Table 4).

Table 4. Standardized coefficients for ordinary least squares (OLS) regression analyses. Only variables significant in the best performing model are included in the table. Note: Ordinal variables are in bold text.

\begin{tabular}{|c|c|c|c|c|}
\hline \multirow[b]{2}{*}{ Available planting space $\left(\mathrm{m}^{2}\right)$} & \multicolumn{2}{|c|}{ Tree richness $^{\dagger}$} & \multicolumn{2}{|c|}{ Canopy cover $(\%)$} \\
\hline & & & 0.367 & $* * *$ \\
\hline Home age (years) & 0.169 & * & 0.397 & $* * *$ \\
\hline Number of trees & 0.652 & $* * *$ & 0.209 & $*$ \\
\hline Education & 0.044 & & 0.215 & $* *$ \\
\hline Income & & & -0.247 & $* * *$ \\
\hline Resident's age (years) & 0.175 & $* *$ & & \\
\hline Rule compliance & -0.126 & $*$ & -0.105 & \\
\hline Collective problem solving & 0.124 & $*$ & & \\
\hline Constitutional rules & 0.144 & $*$ & & \\
\hline Norms & & & 0.142 & \\
\hline Adjusted $\mathrm{R}^{2}$ & 0.582 & & 0.535 & \\
\hline
\end{tabular}

\section{DISCUSSION}

\section{Patterns of rules-in-use, norms, and social capital}

Key to interpreting our results is an understanding that humans ultimately decide patterns of tree cover in urban areas through active and passive decisions (Zipperer et al. 1997); those decisions are influenced by institutions, be they formal or informal, at multiple scales (Fig. 1; Ostrom 2005). Attempts to understand such institutions and their impact on household decision making regarding residential tree care has thus far been limited. The SES framework provides a lens under which varied rules-in-use across household- and neighborhood-scales can be conceptualized and examined.

In our sample, all parcels were subject to the same municipal codes and regulations, but HOA parcels were governed by CCRs as well, so it is not surprising that rule compliance was significantly more important to HOA respondents than NA respondents. A greater threat of sanctions exists for HOA parcels, which we reason incentivizes the importance of rule compliance. Neighborhood norms, including the expectations and values imparted on households by neighbors, were also significantly more important to HOA respondents than NA respondents. Though not legally enforceable, social mores among neighbors often help define what is (and is not) acceptable in yards and may constrain human behavior because of fear of social censure. The presence of rules within HOAs likely establishes a sense of shared responsibilities to a certain yard aesthetic, thus implying that shared norms can play an important complementary role to community rules-inuse. Such rules and norms may also be impacted by legacies imparted by the developer. Cities often enter into agreements with developers during planning stages that establish conservation easements or tree preservation easements, which may then become covenants of the development that are enforced (or possibly forgotten) by the city, HOA, or NA. Thus, in some ways, the common physical structure expected of HOA parcels can be traced back to the developer of the property (Fig. 1), supporting a sense of normative landscaping.

Interestingly, divergent levels of agreement regarding the opportunities afforded for collective problem solving were evident. Although formal institutions establish collective choice arrangements within HOAs (e.g., establishment of regular board meetings), our survey data suggest that the informal institutions within NA communities may provide more opportunities for community problem solving. One possible explanation is that such opportunities do not require formalities, some of which may actually hinder collective problem solving. For instance, a collective choice requirement that a particular proportion of a community be present to vote on an issue, a common collective choice rule in our HOAs, may hinder resolution if attendance is not met. Without strict collective choice rules, NAs may be more flexible to make such arrangements at the convenience of households. This is not to suggest a superior strategy; however, this result demonstrates that formality is not a prerequisite of successful collective action (Gibson 2005).

Comparisons of the importance of collective problem solving (along with rule compliance and norms) between HOA and NA respondents may be confounded by a second variable: neighborhood age. Older neighborhoods were more likely to agree that their neighborhood provided opportunities for collective problem solving. As discussed by Ostrom (2005), learning is enhanced when situations are repeated through improved understanding of others' strategies, which can facilitate convergence of individuals' mental models. Presumably, the older a community, the more chance that repeated interactions have taken place between neighbors allowing for convergence toward problem solving.

\section{Determinants of residential tree composition and cover}

Parcel-scale canopy cover and tree species richness were related to several explanatory variables, though some key differences in the models were apparent. Inclusive of all parcels in the study area, governance variables were more strongly correlated with tree species richness whereas variables reflecting socioeconomic status and education were more strongly correlated with canopy cover (Table 4). Common across both models was the significance of property-level biophysical characteristics, such as home age and number of trees on the property.

\section{Biophysical variables}

In terms of the biophysical characteristics (RU and RS variables), the number of trees per parcel was a significant and positive determinant of both tree species richness and canopy cover (Table 4), although more strongly related to richness than canopy. This relationship is not surprising, whether trees on parcels originated through planting or natural regeneration, every additional individual increases the probability of introducing a new species to the parcel. Additional individual trees, even if small statured, can only increase canopy cover, unless their canopy is covered by another tree's canopy of greater height, in which case they have no effect. This points to a simple, but salient point: urban forest management institutions that incentivize tree planting may increase the probability of greater parcel-scale diversity and canopy cover. 
The positive and significant relationship between home age and tree composition and cover for all parcels together reinforces work by Grove et al. (2006), Troy et al. (2007), Clark et al. (2013), and others who have highlighted the importance of legacies on the urban landscape. Tree cover increases with development age, in part due to longevity of the tree resource and the challenges and costs of removal. In our sample, the oldest parcels were between 45 and 55 years, an age that has been associated with having high canopy due to the presence of mature trees (Grove et al. 2006). More time since development also increases the probability that a new species will either be planted or naturally recruited, resulting in higher tree richness (though such processes may be moderated by the available growing space). In comparison, younger neighborhoods typically have lower canopy cover because of the short time since development, and in our sample, fewer trees given smaller parcels and plantable areas. Our sample did not include neighborhoods older than 60 years, an age likely to correspond to older tree populations and thus greater tree mortality with resulting negative impacts on canopy cover. In selecting our sample population, we struggled to identify older HOAs within city limits, likely because of their recent popularity in Bloomington. This reflects a larger trend in the U.S. because the number of HOAs grew from a few thousand in the 1970s to nearly 350,000 by 2016 (Community Associations Institute 2016).

Plantable space available for trees was not a significant determinant of tree species richness but it was strongly associated with canopy cover. Area has long been theorized to have a positive effect on species richness in natural landscapes (Preston 1962, MacArthur and Wilson 1967); however, the richness-area relationship in intensively managed urban landscapes is less understood given the patchwork mosaic of land uses, ownership types, and number of actors making decisions about the landscape at small and large scales. Though plantable space was not a significant driver of parcel-scale species richness, there was a significant and positive correlation between the two measures at the 0.01 level $(\rho=0.551)$. This relationship warrants further study, particularly because the urban form of residential parcels experiences shifts to accommodate rising demand and rising land costs. Work by Larsen and Hall (2008) suggests these changes have resulted in smaller average lot sizes in residential developments, which influences landscaping opportunities and behavior. How such changes impact tree planting decisions and outcomes of tree species richness is not well understood. Our work suggests that lot size and the plantable space per lot does impact canopy cover. In our study, larger properties had more canopy and more trees than smaller properties, but did not have a proportionately larger area canopy free. This suggests that larger properties have greater potential for canopy cover and associated provision of ecosystem services. Because residential parcels play a large role in determining the canopy cover of the urban forest collectively, consideration of parcel size may be an important factor in setting and achieving municipal canopy goals.

\section{Governance variables}

The tree-richness model retained each of the governance systems (GS) variables, with positive and significant relationships found between constitutional rules and tree species richness, and collective-problem solving and tree species richness. Operational rule compliance, conversely, was identified as an important but negative determinant of both tree species richness and canopy cover. One possible explanation of these results can be gleaned from examination of the tree management rules laid out in city ordinances and CCRs. Most of these rules relate to tree removal practices and establish barriers to planting (where and what species); no rules exist that encourage tree planting or the diversification of planted trees. For instance, although CCRs and city rules require the removal of dead or dying trees, some also require gaining approval prior to planting trees, or they restrict plantings in easement areas or in setbacks. Given this, if rule compliance is important to a household, fewer trees and likely fewer species may exist on the parcel regardless of association type because compliant-focused households may experience higher transaction costs through planting permit requirements, and constrained planting locations and species options. Supporting this argument, a negative correlation between operational rule compliance and tree abundance was noted across the entire data set.

When city ordinances exist to encourage tree plantings or the expansion of canopy cover, much focus has been given to native tree plantings, a strategy meant to reduce the spread of non-native exotic species. However, this strategy can result in over-reliance on a small, nondiverse list of tree species (Sjöman et al. 2016, Conway et al. 2019). In rapidly urbanizing areas, trees are increasingly planted in stressful sites in which only a few, often non-native, species perform well (Almas and Conway 2016). The sustained provisioning of ecosystem services may therefore best be obtained by shifting priorities away from native tree plantings to prioritizing species diversity, including non-native and native species that are known performers in the area. For those households for which city or association rule compliance is important, additional rules that incentivize diversified tree planting may have a positive effect on species richness (and canopy). Although cities may struggle to gain support in imposing such detailed requirements on private parcels, neighborhood scale decision making could play an important role through the creation of formal and informal rules that institutionalize biodiversity. Such rules could potentially increase the ecological resilience of tree structure and the robustness of community urban forest management.

\section{Social variables}

Great attention has been drawn to the luxury effect hypothesis, which contends that higher income provides greater resources for managing extensive plant assemblages (Hope et al. 2003, Kinzig et al. 2005, Lowry et al. 2012) and/or more extensive tree canopies (Iverson and Cook 2000, Luck et al. 2009, Schwarz et al. 2015). Within different cities, studies have demonstrated a positive relationship between tree-canopy cover and education (Luck et al. 2009, Nesbitt et al. 2019) and tree-canopy cover and income (Iverson and Cook 2000, Greene et al. 2018, Nesbitt et al. 2019), with a recent meta-analysis by Gerrish and Watkins (2018) demonstrating substantial levels of income-based inequity for urban forest cover across small and large cities. In our work, variables reflecting socioeconomic status and education were more strongly correlated with canopy cover than tree species richness, but in some unexpected ways. A positive relationship was found between tree-canopy cover and education, supporting the work of other scholars (e.g., Luck et al. 2009, Nesbitt et al. 2019), but a negative relationship was found between canopy cover and income (Table 4). This negative relationship may be 
confounded by the fact that higher income households were more often associated with HOA properties where canopy cover was lower.

Further, although positive correlations between income and education are often reported in the literature, in our sample, the correlation was not strong $(\rho=0.319)$, which may be attributed to the demographic nature of our sampling location, i.e., a small, college town characterized by high human capital but relatively few employment opportunities. Such a scenario may have a decoupling effect on socio-economic variables. Regardless, our sample points to opposing associations of education and income with canopy, and suggests the potential that knowledge of tree benefits (if linked to higher levels of educational attainment) may be a mechanism of influence on the maintenance of residential tree canopy and tree diversity. Further research is needed to explore this hypothesis.

\section{Limitations}

The adjusted $\mathrm{R}^{2}$ values in this study ranged from 0.535 to 0.582 , indicating that $53 \%$ to $58 \%$ of the variation in tree measures was explained by the property, household, and institutional variables included in this study. An additional set of variables, in particular, those that focus on yard characteristics could shed light on the unexplained variability in residential tree dynamics. For example, other scholars have examined the presence and extent of edible gardens, which could influence the amount of canopy desired by homeowners (e.g., Shakeel and Conway 2014). The property location relative to a park may also have an impact on residential tree cover, with houses close to public greenspaces hypothesized to have more trees based on the influence of landscaping norms (Shakeel and Conway 2014).

Other ecological variables that may improve explanatory power include assessments of soil conditions (Schmitt-Harsh et al. 2013) and tree condition and tree maintenance activities, such as pruning, watering, and mulching. The latter variables, though unlikely to have an impact on residential tree biodiversity, may be influential in determining tree canopy and the health and growth of trees (UNRI 2010, Vogt et al. 2015b). Currently, the "E" variable in the SES framework remains underdeveloped because the framework, by implicit but perhaps unintentional design, largely suggests that all outcomes in a social-ecological system can be understood by examining social processes and the institutions that inform human decisions (Epstein et al. 2013, Vogt et al. 2015a). Ecological attributes and processes remain less integrated into the framework; however, as the SES framework continues to evolve (Partelow 2018), more inclusive consideration of ecological attributes will improve the diagnostic capabilities of the framework.

\section{CONCLUSIONS}

This research demonstrates how the SES framework, including the institutional analysis and theory that informs it, can be operationalized to understand residential tree composition and cover. It reinforces the concept of legacy effects on urban forest structure as time because development and parcel structure appear to be important drivers. Socioeconomic variables are associated with residential tree canopy in this study but are confounded in part by the demographic nature of the study location and parallel stratifications of demographics with neighborhood type and form. Perhaps most importantly, the study points to the role of operational rules and their potential for unintended consequences related to determining parcel-scale tree structure. This is an important finding given our gap in understanding the influence of institutions on residential tree composition and cover.

If current arboriculture and urban forestry standards and metrics are considered during rule formation and implementation, such rules have the potential to promote sustainable urban forest structure. For example, such rules might specifically call for diversified tree plantings and the maintenance of specific size classes of trees, assuming good tree health and absence of infrastructure conflict. Regulatory oversight might also focus on discouraging non-native invasive trees and shrubs, while at the same time accepting native and non-native species that have become naturalized into the urban landscape. In this way, urban forest institutions could incentivize the planting and management of diverse assemblages of tree species and their associated canopy, which may aid in countering the biophysical and social drivers of urban forest structure that may be more difficult to adjust for (e.g., variability in education and income). Thus, this research demonstrates the importance of city and neighborhood (HOA and NA) rules in structuring urban forests and implicates the nature of those rules in sustainable urban forest management.

Responses to this article can be read online at: http://www.ecologyandsociety.org/issues/responses. $\mathrm{php} / 11564$

\section{Acknowledgments:}

Funding for this research was provided by the Indiana University Center for Research in Environmental Sciences. The authors thank survey participants for providing access to their parcels, and Matt Patterson, Burney Fischer, and Tom Evans for their supportive role in the project development stage.

\section{Data Availability Statement:}

The datalcode that support the findings of this study are available on request from the corresponding author [MSH]. The datalcode are not publicly available because they contain information that could compromise the privacy of research participants.

\section{LITERATURE CITED}

Almas, A. D., and T. M. Conway. 2016. The role of native species in municipal urban forest planning and practice, a case study of Carolinian Canada. Urban Forestry and Urban Greening 17 (256):54-62. https://doi.org/10.1016/j.ufug.2016.01.015

Alvey, A. A. 2006. Promoting and preserving biodiversity in the urban forest. Urban Forestry and Urban Greening 5:195-201. https://doi.org/10.1016/j.ufug.2006.09.003

Avolio, M. L., D. E. Pataki, T. W. Gillespie, G. D. Jenerette, H. R. McCarthy, S. Pincetl, and L. W. Clarke. 2015b. Tree diversity in southern California's urban forest: the interacting roles of 
social and environmental variables. Frontiers in Ecology and Evolution 3:73. https://doi.org/10.3389/fevo.2015.00073

Avolio, M. L., D. E. Pataki, G. D. Jenerette, S. Pincetl, L. W. Clarke, J. Cavender-Bares, T. W. Gillespie, S. E. Hobbie, K. L. Larson, H. R. McCarthy, and T. L. E. Trammell. 2020. Urban plant diversity in Los Angeles, California: species and functional type turnover in cultivated landscapes. Plants, People, Planet 2:144-156. https://doi.org/10.1002/ppp3.10067

Avolio, M. L., D. E. Pataki, S. Pincetl, T. W. Gillespie, G. D. Jenerette, and H. R. McCarthy. 2015a. Understanding preferences for tree attributes: the relative effects of socioeconomic and local environmental factors. Urban Ecosystems 18:73-86. https://doi.org/10.1007/s11252-014-0388-6

Basurto, X., S. Gelcich, and E. Ostrom. 2013. The social ecological system framework as a knowledge classificatory system for benthic small-scale fisheries. Global Environmental Change 23 (6):1366-1380. http://dx.doi.org/10.1016/j.gloenvcha.2013.08.001

Binder, C. R., J. Hinkel, P. W. G. Bots, and C. Paul-Wostl. 2013. Comparisons of frameworks for analyzing social-ecological systems. Ecology and Society 18(4):26. https://doi.org/10.5751/ ES-05551-180426

Blaine, T. W., S. Clayton, P. Robbins, and P. S. Grewal. 2012. Homeowner attitudes and practices towards residential landscape management in Ohio, USA. Environmental Management 50:257-271. https://doi.org/10.1007/s00267-012-9874-X

Boone, C. G., M. L. Cadenasso, J. M. Grove, K. Schwarz, and G. L. Buckley. 2010. Landscape, vegetation characteristics, and group identify in an urban and suburban watershed: why the $60 \mathrm{~s}$ matter. Urban Ecosystems 13:255-271. https://doi.org/10.1007/ $\underline{\mathrm{s} 11252-009-0118-7}$

Chowdhury, R. R., K. Larson, M. Grove, C. Polsky, E. Cook, J. Onsted, and L. Ogden. 2011. A multiscalar approach to theorizing socio-ecological dynamics in urban residential landscapes. Cities and the Environment 4(1):6. https://doi.org/10.15365/cate.4162011

Clark, J. R., N. P. Matheny, G. Cross, and V. Wake. 1997. A model of urban forest sustainability. Journal of Arboriculture 23 (1):17-30. [online] URL: https://urbanforestrysouth.org/resources/ library/citations/a-model-of-urban-forest-sustainability-1

Clarke, J. W., G. D. Janerette, and A. Davila. 2013. The luxury of vegetation and the legacy of tree biodiversity in Los Angeles, CA. Landscape and Urban Planning 116:48-59. https://doi. org/10.1016/j.landurbplan.2013.04.006

Community Associations Institute. 2016. National and state statistical review for 2016. Community Associations Institute, Falls Church, Virginia, USA. [online] URL: https://foundation. caionline.org/wp-content/uploads/2017/07/2016StatsReviewFBWeb. pdf

Conway, T. M. 2016. Tending their urban forest: residents' motivations for tree planting and removal. Urban Forestry and Urban Greening 17:23-32. https://doi.org/10.1016/j.ufug.2016.03.008

Conway, T. M., A. D. Almas, and D. Coore. 2019. Ecosystem services, ecological integrity, and native species planting: how to balance these ideas in urban forest management? Urban Forestry and Urban Greening 41:1-5. https://doi.org/10.1016/j.ufug.2019.03.006
Cook, E. M., S. J. Hall, and K. L. Larson. 2012. Residential landscapes as social-ecological systems: a synthesis of multiscalar interactions between people and their home environment. Urban Ecosystems 15:19-52. https://doi.org/10.1007/s11252-011-0197-0

Cox, M. 2014. Applying a social-ecological system framework to the study of the Taos Valley irrigation system. Human Ecology 42(2):311-324. http://dx.doi.org/https://doi.org/10.1007/s10745-014-9651$\underline{Y}$

Crawford, S. E. S., and E. Ostrom. 1995. A grammar of institutions. American Political Science Review 89(3):582-600. http://dx.doi.org/10.2307/2082975

Dilley, J., and K. L. Wolf. 2013. Homeowner interactions with residential trees in urban areas. Arboriculture and Urban Forestry 39(6):267-277. [online] URL: https://www.fs. usda.gov/treesearch/ pubs/45809

Dillman, D. A. 2007. Mail and internet surveys: the tailored design method. Wiley, New York, New York, USA.

Dwyer, J. F., D. J. Nowak, M. H. Noble, and S. M. Sisinni. 2000. Connecting people with ecosystems in the 21st century: an assessment of our nation's urban forests. General Technical Report PNW-GTR-490. USDA Forest Service Pacific Northwest Research Station, Portland, Oregon, USA. [online] URL: https:// www.fs.usda.gov/treesearch/pubs/29448

Epstein, G., J. M. Vogt, S. K. Mincey, M. Cox, and B. Fischer. 2013. Missing ecology: integrating ecological perspectives with the social-ecological system framework. International Journal of the Commons 7(2):432-453. http://dx.doi.org/10.18352/ijc.371

Fleischman, F., K. Boenning, G. A. Garcia-Lopez, S. Mincey, M. Schmitt-Harsh, K. Daedlow, M. C. López, X. Basurto, B. C. Fischer, and E. Ostrom. 2010. Disturbance, response, and persistence in self-organized forested communities: analysis of robustness and resilience in five communities in southern Indiana. Ecology and Society 15(4):9. http://dx.doi.org/10.5751/ES-03512-150409

Fraser, J. C., J. T. Bazuin, L. E. Band, and J. M. Grove. 2013. Covenants, cohesion, and community: the effects of neighborhood governance on lawn fertilization. Landscape Urban Planning 115:30-38. https://doi.org/10.1016/j.landurbplan.2013.02.013

Gerrish, E., and S. L. Watkins. 2018. The relationship between urban forests and income: a meta-analysis. Landscape and Urban Planning 170:293-308. https://doi.org/10.1016/j.landurbplan.2017.09.005

Gibson, C. C. 2005. Applying the IAD framework: incentives inside a development agency. Pages 131-160 in C. C. Gibson, K. Andersson, E. Ostrom, and S. Shivakumar, editors. The Samaritan's dilemma. Oxford University Press, Oxford, UK. https://doi.org/10.1093/0199278857.003.0007

Goddard, M. A., A. J. Dougill, and T. G. Benton. 2013. Why garden for wildlife? Social and ecological drivers, motivations and barriers for biodiversity management in residential landscapes. Ecological Economics 86:258-273. https://doi.org/10.1016/j. ecolecon.2012.07.016

Greene, C. S., P. J. Robinson, and A. A. Millward. 2018. Canopy of advantage: who benefits most from city trees? Journal of Environmental Management 208(15):24-35. https://doi.org/10.1016/ j.jenvman.2017.12.015 
Grove, J. M., A. R. Troy, J. P. M. O’Neil-Dunne, W. R. Burch, Jr., M. L. Cadenasso, and S. T. A. Pickett. 2006. Characterization of households and its implications for the vegetation of urban ecosystems. Ecosystems 9(4):578-597. https://doi.org/10.1007/ $\underline{\text { s10021-006-0116-Z }}$

Hale, J. D., T. A. M. Pugh, J. P. Sadler, C. T. Boyko, J. Brown, S. Caputo, M. Caserio, R. Coles, R. Farmani, C. Hales, R. Horsey, D. V. L. Hunt, J. M. Leach, C. D. F.Rogers, and A. R. MacKenzie. 2015. Delivering a multi-functional and resilient urban forest. Sustainability 7:4600-4624. https://doi.org/10.3390/su7044600

Hill, J. R. 2011. Surficial geology - landscapes of Indiana. Indiana Geological Survey, Indiana University. Bloomington, Indiana, USA. [online] URL: http://igs.indiana.edu/Surficial/Landscapes. $\underline{\mathrm{cfm}}$

Hope, D., C. Gries, W. Zhu, W. F. Fagan, C. L. Redman, N. B. Grimm, A. L. Nelson, C. Martin, and A. Kinzig. 2003. Socioeconomics drive urban plant diversity. Proceedings of the National Academy of Sciences 100:8788-8792. https://doi. org/10.1073/pnas. 1537557100

Iverson, L. R., and E. A. Cook. 2000. Urban forest cover of the Chicago region and its relation to household density and income. Urban Ecosystems 4:105-124. https://doi.org/10.1023/A:1011307327314

Kenney, W. A., P. J. Van Wassenaer, and A. L. Satel. 2011. Criteria and indicators for strategic urban forest planning and management. Arboriculture and Urban Forestry 37(3):108-117.

Kinzig, A. P., P. Warren, C. Martin, D. Hope, and M. Katti. 2005. The effects of human socioeconomic status and cultural characteristics on urban patterns of biodiversity. Ecology and Society 10(1):23. https://doi.org/10.5751/ES-01264-100123

Landry, S. M., and J. Chakraborty. 2009. Street trees and equity: evaluating the spatial distribution of an urban amenity. Environmental Planning A 41:2651-2670. https://doi.org/10.1068/ $\underline{\mathrm{a} 41236}$

Larsen, L., and S. J. Hall. 2008. Social-ecological dynamics of residential landscapes: human drivers of management practices and ecological structure in an urban ecosystem context. Interdisciplinary Graduate Research and Education Training (IGERT) workshop report from the Global Institute of Sustainability, Arizona State University-Tempe, Tempe, Arizona, USA.

Larsen, L., and S. L. Harlan. 2006. Desert dreamscapes: residential landscape preference and behavior. Landscape and Urban Planning 78:85-100. https://doi.org/10.1016/j. landurbplan.2005.06.002

Larson, K. L., D. Casagrande, S. L. Harlan, and S. T. Yabiku. 2009. Residents' yard choices and rationales in a desert city: social priorities, ecological impacts, and decision tradeoffs. Environmental Management 44:921-937. https://doi.org/10.1007/ s00267-009-9353-1

Leslie, H. M., X. Basurto, M. Nenadovic, L. Sievanen, K. C. Cavanaugh, J. J. Cota-Nieto, B. E. Erisman, E. Finkbeiner, G. Hinojosa-Arango, M. Moreno-Báez, S. Nagavarapu, S. M. W. Reddy, A. Sánchez-Rodríguez, K. Siegel, J. J. UlibarriaValenzuela, A. H. Weaver, and O. Aburto-Oropeza. 2015. Operationalizing the social-ecological systems framework to assess sustainability. Proceedings of the National Academy of Sciences 112(19):5979-5984. http://dx.doi.org/10.1073/pnas.1414640112

Locke, D. H., M. Avolio, T. L. E. Trammell, R. R. Chowdhury, J. M. Grove, J. Rogan, D. G. Martin, N. Bettez, J. Cavender-Bares, P. M. Groffman, S. J. Hall, J. B. Heffernan, S. E. Hobbie, K. L. Larson, J. L. Morse, C. Neill, L. A. Ogden, J. P. M. O'Neil-Dunne, D. Pataki, W. D. Pearse, C. Polsky, and M. M. Wheeler. 2018. A multi-city comparison of front and backyard differences in plant species diversity and nitrogen cycling in residential landscapes. Landscape and Urban Planning 178:102-111. https://doi. org/10.1016/j.landurbplan.2018.05.030

Lowry, Jr., J. H., M. E. Baker, and R. D. Ramsey. 2012. Determinants of urban tree canopy in residential neighborhoods: household characteristics, urban form, and the geophysical landscape. Urban Ecosystems 15:247-266. https://doi.org/10.1007/ s11252-011-0185-4

Luck, G. W., L. T. Smallbone, and R. O’Brien. 2009. Socioeconomics and vegetation change in urban ecosystems: patterns in space and time. Ecosystems 12:604-620. https://doi. org/10.1007/s10021-009-9244-6

MacArthur, R. H., and E. O. Wilson. 1967. The theory of island biogeography. Princeton University Press, Princeton, New Jersey, USA. https://doi.org/10.1515/9781400881376

Martin, C. A., K. A. Peterson, and L. B. Stabler. 2003. Residential landscaping in Phoenix, Arizona, USA: practices and preferences relative to covenants, codes and restrictions. Journal of Arboriculture 29(1):9-17. [online] URL: https://pdfs.semanticscholar. org/960c/748a08cf30a7feac65fbcf8f5fe7e0df0dc1.pdf

Martin, C. A., P. S. Warren, and A. P. Kinzig. 2004. Neighborhood socioeconomic status is a useful predictor of perennial landscape vegetation in residential neighborhoods and embedded small parks of Phoenix, AZ. Landscape and Urban Planning 69:355-368. https://doi.org/10.1016/j.landurbplan.2003.10.034

McBride, Dale, Clarion. 2019. City of Bloomington: unified development ordinance. City of Bloomington, Bloomington, Indiana, USA. [online] URL: https://bloomington.in.gov/ planning/udo

McGinnis, M. D., and E. Ostrom. 2014. Social-ecological system framework: initial changes and continuing challenges. Ecology and Society 19(2):30. http://dx.doi.org/10.5751/ES-06387-190230

Mincey, S. K., M. Hutten, B. C. Fischer, T. P. Evans, S. I. Stewart, and J. M. Vogt. 2013a. Structuring institutional analysis for urban ecosystems: a key to sustainable urban forest management. Urban Ecosystems 16:553-571. https://doi.org/10.1007/s11252-013-0286-3

Mincey, S. K., M. Schmitt-Harsh, and R. Thurau. 2013b. Zoning, land use, and urban tree canopy cover: the importance of scale. Urban Forestry and Urban Greening 12:191-199. https://doi. org/10.1016/j.ufug.2012.12.005

Nassauer, J. I., Z. Wang, and E. Darrell. 2009. What will the neighbors think? Cultural norms and ecological design. Landscape and Urban Planning 92:282-292. https://doi. org/10.1016/j.landurbplan.2009.05.010

Nesbitt, L., M. J. Meitner, C. Girling, S. R. J. Sheppard, and Y. Lu. 2019. Who has access to urban vegetation? A spatial analysis 
of distributional green equity in 10 US cities. Landscape and Urban Planning 181:51-79. https://doi.org/10.1016/j.

landurbplan.2018.08.007

Ostrom, E. 2005. Understanding institutional diversity. Princeton University Press, Princeton, New Jersey, USA.

Ostrom, E. 2007. A diagnostic approach for going beyond panaceas. Proceedings of the National Academy of Sciences 104 (39):15181-15187. https://doi.org/10.1073/pnas.0702288104

Ostrom, E. 2009. A general framework for analyzing the sustainability of social-ecological systems. Science 325 (5939):419-422. http://dx.doi.org/10.1126/science.1172133

Partelow, S. 2018. A review of the social-ecological systems framework: applications, methods, modifications, and challenges. Ecology and Society 23(4):36. https://doi.org/10.5751/ES-10594-230436

Partelow, S., P. Senff, N. Buhari, and A. Schlüter. 2018. Operationalizing the social-ecological systems framework in pond aquaculture. International Journal of the Commons 12 (1):485-518. http://dx.doi.org/https://doi.org/10.18352/ijc.834

Preston, F. W. 1962. The canonical distribution of commonness and rarity. Ecology 43(2):185-215. https://doi.org/10.2307/1931976

Robbins, P., A. Polderman, and T. Birkenholtz. 2001. Lawns and toxins: an ecology of the city. Cities 18(6):369-380. https://doi. org/10.1016/s0264-2751(01)00029-4

Sampson, R. J., S. W. Raudenbush, and F. Earls. 1997. Neighborhoods and violent crime: a multilevel study of collective efficacy. Science 277(5328):918-924. https://doi.org/10.1126/ science. 277.5328 .918

Schmitt-Harsh, M., S. K. Mincey, M. Patterson, B. C. Fischer, and T. P. Evans. 2013. Private residential forest structure and carbon storage in a moderate-sized urban area in the Midwest, United States. Urban Forestry and Urban Greening 12:454-463. https://doi.org/10.1016/j.ufug.2013.07.007

Schwarz, K., M. Fragkias, C. G. Boone, W. Zhou, M. McHale, J. M. Grove, J. O’Neil-Dunne, J. P. McFadden, G. L. Buckley, D. Childers, L. Ogden, S. Pincetl, D. Pataki, A. Whitmer, and M. L. Cadenasso. 2015. Trees grow on money: urban tree canopy cover and environmental justice. PLoS One 10:e0122051. https://doi. org/10.1371/journal.pone.0122051

Shakeel, T., and T. M. Conway. 2014. Individual households and their trees: fine-scale characteristics shaping urban forests. Urban Forestry and Urban Greening 13:136-144. https://doi.org/10.1016/ j.ufug.2013.11.004

Sjöman, H., J. Morgenroth, J. D. Sjöman, A. Sæbø, and I. Kowarik. 2016. Diversification of the urban forest: can we afford to exclude exotic tree species? Urban Forestry and Urban Greening 18:237-241. https://doi.org/10.1016/j.ufug.2016.06.011

Smith R. M., K. Thompson, J. G. Hodgson, P. H. Warren, and K. J. Gaston. 2006. Urban domestic gardens (IX): composition and richness of the vascular plant flora, and implications for native biodiversity. Biological Conservation 129(3):312-322. https://doi.org/10.1016/j.biocon.2005.10.045

Troy, A. R., J. M. Grove, J. P. M. O’Neil-Dunne, S. T. A. Pickett, and M. L. Cadenasso. 2007. Predicting opportunities for greening and patterns of vegetation on private urban lands. Environmental Management 40:394-412. https://doi.org/10.1007/s00267-006-0112-2

Urban Natural Resources Institute (UNRI). 2010. Standards for urban forestry data collection: a field guide, draft 2.0. International Union of Forest Research Organizations, Vienna, Austria; International Society of Arboriculture, Atlanta, Georgia, USA; United States Forest Service, Washington, D.C., USA; and Urban Natural Resources Institute, Washington, D.C., USA. [online] URL: http://www.unri.org/standards/wp-content/uploads/2010/08/ Version-2.0-082010.pdf

U.S. Census Bureau. 2010. State and county quick facts: Indianapolis, Indiana. U.S. Census Bureau, Washington, D.C., USA. [online] URL: https://www.census.gov/quickfacts/fact/ table/US/PST045219

Vogt, J. M., G. B. Epstein, S. K. Mincey, B. C. Fischer, and P. McCord. 2015a. Putting the "E" in SES: unpacking the ecology in the Ostrom social-ecological system framework. Ecology and Society 20(1):55. http://dx.doi.org/10.5751/ES-07239-200155

Vogt, J. M., S. L. Watkins, S. K. Mincey, M. S. Patterson, and B. C. Fischer. 2015b. Explaining planted-tree survival and growth in urban neighborhoods: a social-ecological approach to studying recently-planted trees in Indianapolis. Landscape and Urban Planning 136:130-143. https://doi.org/10.1016/j.landurbplan.2014.11.021

Wentz, E. A., S. Rode, X. Li, E. M. Tellman, and B. L. Turner, II. 2016. Impact of homeowner association (HOA) landscaping guidelines on residential water use. Water Resources Research 52:3373-3386. https://doi.org/10.1002/2015WR018238

Yabiku, S. T., D. G. Casagrande, and E. Farley-Metzger. 2008. Preferences for landscape choice in a southwestern desert city. Environment and Behavior 40(3):382-400. https://doi. org/10.1177/0013916507300359

Zipperer, W. C., S. M. Sissinni, R. V. Pouyat, and T. W. Foresman. 1997. Urban tree cover: an ecological perspective. Urban Ecosystems 1:229-246. https://doi.org/10.1023/A:1018587830636 
Appendix 1. Survey questions that were analyzed to operationalize the SES framework. The full survey instrument had 37 questions and was distributed to owner-occupied, single-family housing units.

1. How long have you lived at this property?

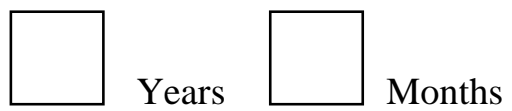

2. How important is "fitting in with the neighborhood" to maintaining this property's landscape? "Landscape" refers to the natural elements (trees, gardens, lawn) of the property excluding built structures (house, sheds, etc.).
Very important
Somewhat important
Not important

3. How important is "complying with City or Neighborhood or Homeowners Associations rules” to maintaining this property's landscape?
Very important
Somewhat important
Not important

4. How strongly would you agree or disagree with the following statements about your neighborhood?
Strongly agree
a. People in the neighborhood are willing to help one another.
b. This is a close-knit neighborhood.
c. People in this neighborhood can be trusted.
d. There are many opportunities to meet neighbors and work on solving community problems together. Strongly Don't
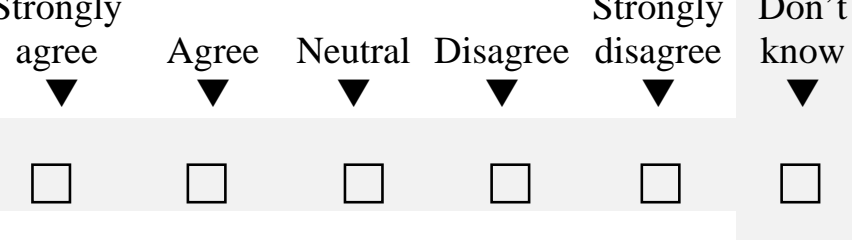

5. Please describe any City rules or restrictions (city ordinance, development code, etc.) that affect the way you manage trees on your property or along the street.

6. Please describe any Neighborhood (NA) or Homeowners Association (HOA) rules that affect the way you manage trees on your property or along the street.

7. Including yourself, how many people live in your household? 
9. What is the highest grade in school you have had the opportunity to complete?

$\square$ high school or equivalent

$\square$ some college or technical

$\square$ college graduate or higher

10. What is the total income of your household?
$\square<\$ 25,000$
$\$ 25,001-\$ 50,000$
$\square \$ 50,001-\$ 75,000$
$\square>\$ 75,001$ 